\title{
Interaction of Trembling Aspen and Lodgepole Pine in a Young Sub-Boreal Mixedwood Stand in Central British Columbia
}

\author{
Amalesh Dhar1,2, Jian R. Wang', Christopher D. B. Hawkins ${ }^{1,4}$ \\ ${ }^{1}$ Mixedwood Ecology and Management Program, University of Northern British Columbia, Prince George, \\ Canada \\ ${ }^{2}$ Earth \& Environmental Sciences and Physical Geography, University of British Columbia, Kelowna, Canada \\ ${ }^{3}$ Faculty of Natural Resource Management, Lakehead University, Thunder Bay, Canada \\ ${ }^{4}$ Yukon Research Centre, Yukon College, Whitehorse, Canada \\ Email: amalesh.dhar@ubc.ca, jian.wang@lakeheadu.ca, chawkins@yukoncollege.yk.ca
}

Received 2 January 2015; accepted 21 January 2015; published 26 January 2015

Copyright (C) 2015 by authors and Scientific Research Publishing Inc.

This work is licensed under the Creative Commons Attribution International License (CC BY). http://creativecommons.org/licenses/by/4.0/

\section{(c) (i) Open Access}

\begin{abstract}
Strategies for managing mixed broadleaf-conifer stands in British Columbia (BC) have been under review in recent years as the benefits of mixedwood management have been recognized. More has been learned about the role of broadleaves in forest ecosystems however ecosystem-specific knowledge about the competitive interactions between mixed broadleaf-conifer stands is still scarce. Therefore a competitive interactions study was conducted to facilitate ecosystem-specific management for lodgepole pine (Pinus contorta Dougl. Ex Loud. Var. latifolia Engelm.) and trembling aspen (Populus tremuloides Michx.) in the sub-boreal spruce (SBS) zone of central BC. The experiment was a completely randomized block design with six different aspen densities replicated three times. Each replicate was sampled three times between ages 14 to 19 years. Pine diameter and height growth were influenced by aspen density. Our current quantitative findings suggest that lodgepole pine growth was not impacted when growing with aspen densities up to 2500 stems ha $^{-1}$. Considering free growing (FTG) and not free growing (NFTG) pine at the time of trial establishment, an insignificant difference was found for $\mathrm{DBH}$, height and crown volume responses. Leaf area index (LAI) and diffuse non-interceptance (DIFN) radiation were also not significantly different between FTG or NFTG trees suggesting our results exceed the current BC's free growing standard. Further work is recommended to determine whether or not the current free growing standards are appropriate for producing the desired crop outcome.
\end{abstract}

\section{Keywords}

Competitive Neighbourhoods, Free Growing, Leaf Area Index, Mixedwood Management, Vegetation

How to cite this paper: Dhar, A., Wang, J. R., \& Hawkins, C. D. B. (2015). Interaction of Trembling Aspen and Lodgepole Pine in a Young Sub-Boreal Mixedwood Stand in Central British Columbia. Open Journal of Forestry, 5, 129-138.

http://dx.doi.org/10.4236/ojf.2015.52013 


\section{Competition}

\section{Introduction}

Trembling aspen (Populus tremuloides Michx.) occurs across a wide range of ecosystems in Canada (Chen et al., 2002) and may be found at all latitudes of interior British Columbia (BC); especially in the central interior of the province, where it regenerates naturally with lodgepole pine (Pinus contorta Dougl. var. latifolia Engelm.) and interior spruce (Picea engelmannii × -glauca) (Newsome et al., 2010, 2003; Kabzems \& Garcia, 2004) following harvesting and natural fire disturbance. It has a potential impact on conifer species such as: retention of nutrients and soil moisture (Man \& Lieffers, 1999; Coopersmith et al., 2000), affecting air and soil temperatures, slowing the spread of Armillaria and Phellinus root rot diseases (Gerlach et al., 1997; Simard et al., 2005) and increaseing mechanical stability (Frivold, 1985; Yang, 1989). Beside these benefits, the aspen over-storey also serves as a nurse crop which diminishes frost and insect damage, reduces competition from under-storey vegetation and significantly contributes to species and structural diversity in mixedwood boreal forests (Man \& Lieffers, 1999).

A variety of mixedwood stands with varying densities of broadleaf and conifer species develop in the subboreal forest as a result of natural stand dynamics following disturbance (Prévost \& Pothier, 2003). Understanding the factors influencing the dynamics of these mixedwood systems will provide the basis for sustainable forest resource development and conservation (Peng et al., 2002). However, mixedwood stands are difficult to manage as they are highly variable in their environmental requirements, regeneration strategies, growth rates, and life span (Prévost \& Pothier, 2003). However recent forest management policy is shifting towards biological/ecosystem-based mixedwood management (Hibbs et al., 1989; Hawkins et al. 2012; Hawkins et al., 2013). Unfortunately current trends of mixedwood management are not well documented due to a limited understanding of the dynamic processes and a lack of predictive models (Hawkins et al., 2012).

In order to develop effective management strategies for broadleaf-conifer mixedwood stands where softwood timber production is the primary objective, silviculturists require information about the level of broadleaves that can be retained without seriously affecting conifer performance. They also require practical ways of using this information to develop cost-effective treatment prescriptions. Up until now, little work has been initiated to identify competition thresholds for aspen-lodgepole pine mixtures to describe where pine survival or growth is significantly impacted (Heineman et al., 2008; Newsome et al., 2003, 2006, 2008, 2010) or canopy light availability is reduced to critical levels (Comeau, 2001; Comeau et al., 2006). Thus there is a need for further investigation to describe aspen-lodgepole pine competitive aspects in central BC forests.

Light availability is particularly important to lodgepole pine because of its low shade tolerance (Klinka \& Scagel, 1984) and when light is limited, stem diameter growth decreases markedly (e.g., Simard et al., 2001). Additionally, lodgepole pine is known to allocate more growth to terminal shoots than lateral shoots, and to reduce branch number in low light environments (Chen et al., 1996). High densities of aspen can reduce light levels where conifer growth is limited for a certain part of the growing season (DeLong \& Tanner, 1996; Coopersmith et al., 2000). Moreover, conifers growing among aspen are also commonly damaged by the "whipping" effect of nearby branches (Lees, 1966). Therefore, the interaction of aspen and pine in relation to light is potentially important for forest managers to meet conifer survival and growth objectives.

During the last two decades, broadcast manual cutting or herbicide treatments have been applied to aspendominated clear-cut sites in central BC to facilitate lodgepole pine survival and growth as well as to ensure that stands can meet the legislated free growing requirements. A free growing stand is defined as "a stand of healthy trees of a commercially valuable species, the growth of which is not impeded by competition from plants, shrubs or other trees” (BC Ministry of Forests, 2005). In BC, free growing guidelines are intended to ensure that conifers are free of competition that could compromise their development over the course of a rotation. Therefore, the current requirement for trees of free growing age to be free of overtopping vegetation within a $1 \mathrm{~m}$ radius sets the standard for conifer performance (BC Ministry of Forests, 2000). However Lieffers et al. (2007) did note that the current free growing definition is an ineffective indicator of future spruce growth in Alberta aspen-spruce forests. Results from our study will provide information for refinement of free growing assessments and free growing policy in central BC. 
The main objectives of this study were to examine the growth response of pine to varying levels of imposed aspen densities and to test the effectiveness of the free growing criterion by comparing ongoing growth and leaf area index (LAI) of lodgepole pine that did or did not meet that specific criterion [free growing (FTG) and not free growing (NFTG)] immediately following density reduction treatments.

\section{Materials and Methods}

\subsection{Study Area}

The study site, Vama Vama Creek, is located in central BC within the Prince George Timber Supply Area (forest district). It is located in the warm cool (wk1) sub zone of the SBS (Sub-Boreal Spruce) biogeoclimatic zone (Meidinger et al., 1991). Soils at the study site are formed on medium-textured (silt loam) morainal deposits. The annual precipitation is about $450 \mathrm{~mm}$ with a mean annual and extremes temperature $2.3^{\circ} \mathrm{C}-45.6^{\circ} \mathrm{C}$ and $+33.7^{\circ} \mathrm{C}$ respectively. The average frost free period is 110 days. The study site is predominantly lodgepole pine and aspen with lesser amounts of interior spruce and subalpine fir [Abies lasiocarpa (Hook.) Nutt]. The mean density prior to density reduction was $11,400 \mathrm{sph}$ (stems-hectare ${ }^{-1}$ ). The experiment was established in a $12-$ year old aspen-pine stand in 1999.

\subsection{Experimental Design and Data Collection}

The experiment was laid out in a completely randomized block design (RCBD) with six nominally different aspen densities or treatments [0, 500, 1200, 2500, $5000 \mathrm{sph}$, plus an untreated control] and replicated three times. Treatments were established in the fall of 1999. To meet the target treatment density, broadleaf species other than aspen were cut within $1.5 \mathrm{~m}$ of lodgepole pine to facilitate the pine aspen competition. At each site, the treated area was $50 \mathrm{~m} \times 50 \mathrm{~m}$ with a permanent sample plot (PSP) in the centre with a radius of $5.64 \mathrm{~m}$ (0.01 ha). In 2000, the total number of different tree species (broadleaf and conifers) the number of aspen stems, their DBH, height, basal area etc. were counted in the $5.64 \mathrm{~m}$ PSP. Similar measurements of all PSP were done in 2002 and 2006. Competition was determined based on relationships between lodgepole pine stem annual diameter increment and aspen density. The height to diameter ratio (HDR), an important measure of tree and stand stability for conifers, was also calculated.

To determine the effectiveness of the legislated free growing criterion (BC Ministry of Forests, 2005), an equal numbers of free growing (FTG) and not free growing (NFTG) lodgepole pine were also selected across the nine ha site and numbered with a metal tag. For free growing criteria (FTG) all aspen within $1 \mathrm{~m}$ radius cylinder centered on the pine were removed whereas for not free growing (NFTG) criteria none of the aspen were removed to facilitate competition. Crown dimensions, total height and DBH were measured for each pine in 2000, 2001, 2003, and 2006.

The leaf area index (LAI) for both FTG and NFTG lodgepole pine was measured at each sample point throughout the investigation area. The light measurements were made using a LiCor LAI-2000 Plant Canopy Analyzer (LiCor Inc., Lincoln Nebraska), where diffuse non-interceptance (DIFN) values are unbiased estimates of average growing season fractional transmittance (i.e., percent of open-sky light) (Comeau et al., 1998). At each tagged pine, understory light measurements were taken $1.3 \mathrm{~m}$ above the ground in order to avoid the influence of understory vegetation. In total, two readings from opposite directions were taken with $180^{\circ}$ view restrictors attached to the sensor at each point in midsummer of 2005. The LiCor system requires open-sky, as well as understory, measurements in order to calculate DIFN.

\subsection{Data Analysis}

All analyses were conducted using the statistical package STSTAT version $12^{\circledR}$. A repeated measure ANOVA was conducted to determine the density effect on lodgpole pine annual DBH increment, height increment and HDR. In addition a simple liner regression analysis was used to examine density-dependent relationships of lodgpole pine growth under variable aspen densities. The impact level of aspen density was identified when the regression analysis changed from significant to non-significant (Hawkins \& Dhar, 2013) in relation to lodgpole pine annual DBH and height increment. The impact levels were identified using a ceiling function which described the upper boundary of the data and enveloped at least 95\% of the observations (Burton, 1993). ANOVA was used to determine differences between FTG and NFTG pine $(\alpha=0.05)$ based on height, diameter, crown 
volume, leaf area index (LAI) and DIFN values. The general tests for normality of data distribution were also carried out before statistical analysis.

\section{Results}

\subsection{Permanent Sample Plots}

Repeated measures analyses of the 2000, 2002 and 2006 data, indicated diameter growth, height growth and HDR were not significantly different among density classes $(p=0.221 ; p=0.353$ and $p=0.400$, respectively). Pine DBH growth showed an irregular response with increased aspen density whereas aspen DBH increased with increased aspen density up to $2500 \mathrm{stems} \mathrm{ha}^{-1}$ (sph) and thereafter decreased (Figure 1). The maximum mean annual diameter growth was found in the $300 \mathrm{sph}$ treatment which is followed by density class 0 , and 2500 sph (Figure 1). Compared to DBH, pine height growth was nearly nonresponsive to aspen density classes (data not presented). Based on simple liner regression analysis, the presence of aspen did not significantly affect DBH growth of lodgpole pine until the density exceeded 2500 sph (Table 1). Conversely, pine height growth was not affected by any aspen density treatment. Height to diameter ratio (HDR), a relative measure of tree slenderness related to growth factors such as light availability and competition, indicated an improved or constant response in all years (2000, 2002 and 2006) except for the control treatment: control HDR increased with time (Figure 2). This suggests that except for the control treatment pine height was increasing, but not at the expense of diameter growth.

\subsection{Responses of Free Growing (FTG) and Not Free Growing (NFTG) Pine}

Repeated measures ANOVA for 2000, 2001, 2003 and 2006 data indicated DBH ( $\mathrm{p}=0.794)$, height $(\mathrm{p}=0.628)$ and crown volume $(\mathrm{p}=0.774)$ were not significantly different between FTG and NFTG pine. Mean height, DBH and crown volume of FTG and NFTG pines showed a similar response except for crown volume (Figure 3). The crown volume of FTG pine decreased with increasing aspen density whereas NFTG pine showed a variable response (Figure 3). Both FTG and NFTG pine had similar mean annual DBH and height growth (data not presented).

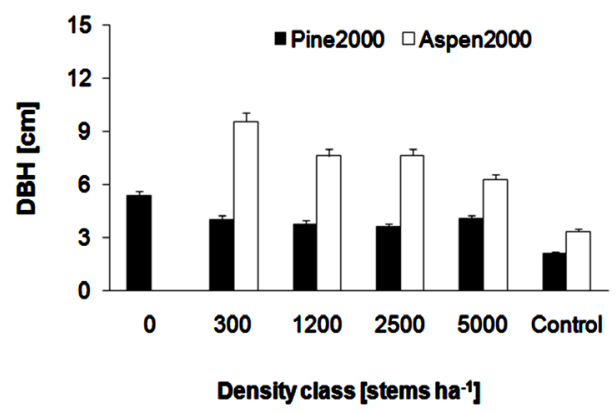

(a)

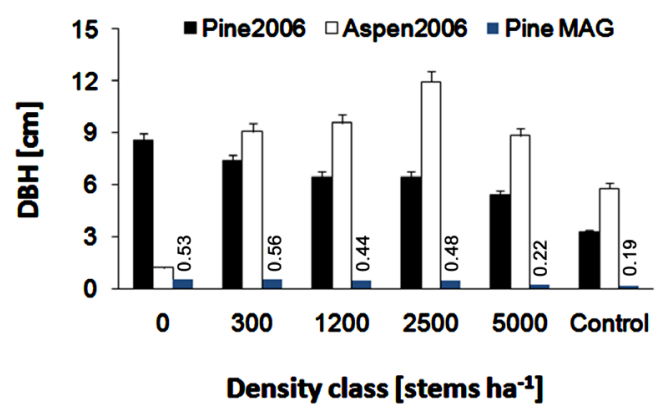

(b)

Figure 1. Mean lodgepole pine and aspen diameter at breast height ( \pm SEM) (a) at plot establishment and (b) after six years with mean annual lodgepole pine DBH growth (pine MAG) by establishment aspen density.

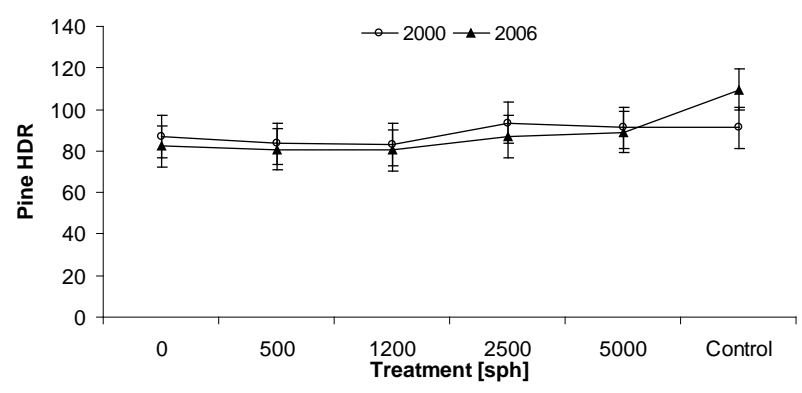

Figure 2. Mean lodgepole pine height-to-diameter ratio (HDR) ( \pm SEM) against aspen density treatments or classes. Only 2000 and 2006 are presented. 

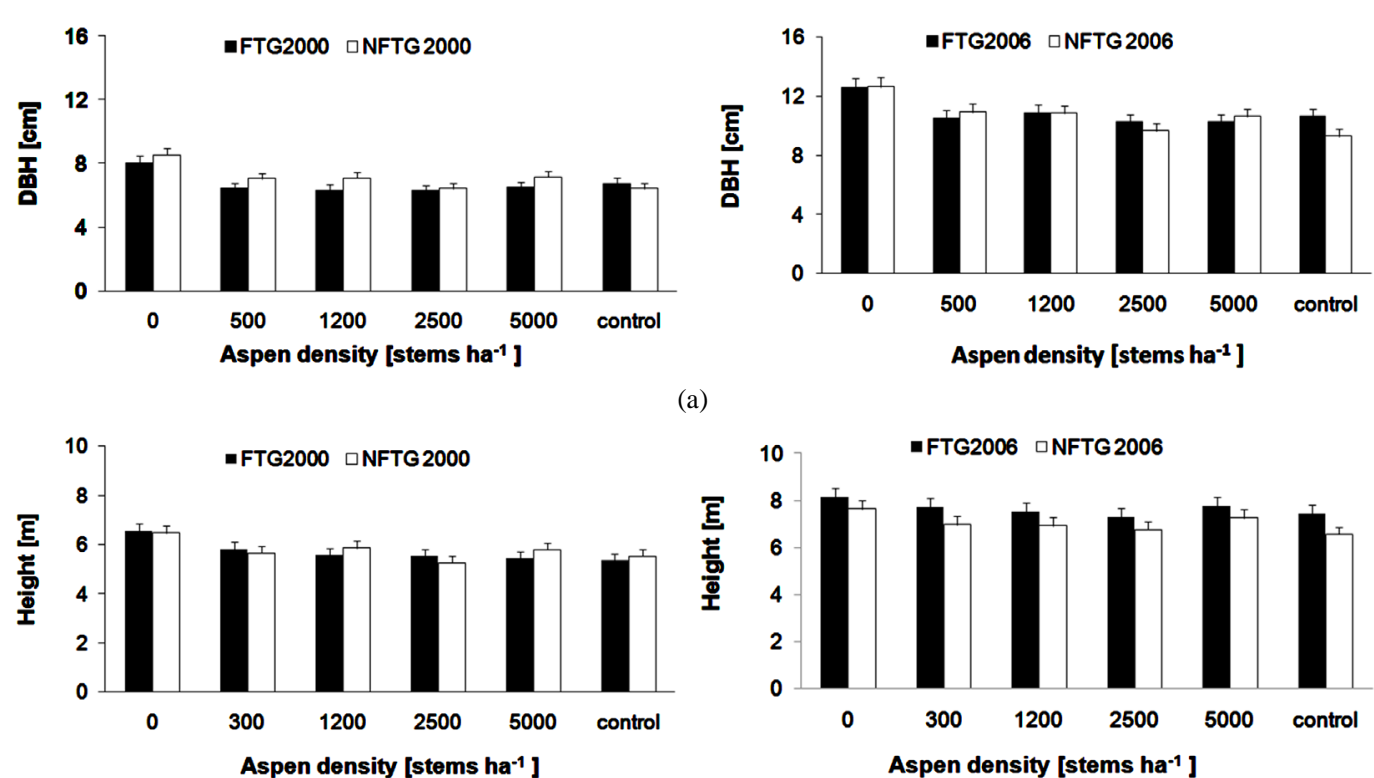

(a)

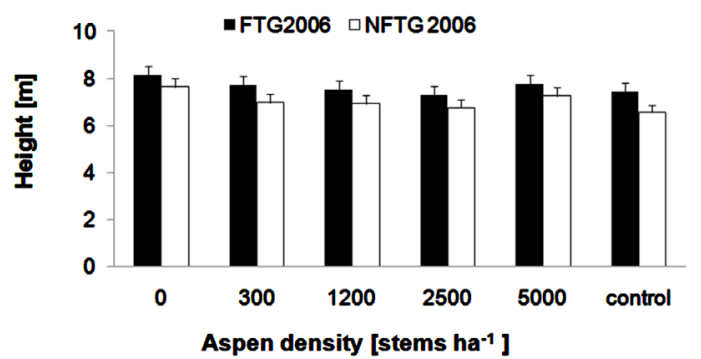

(b)
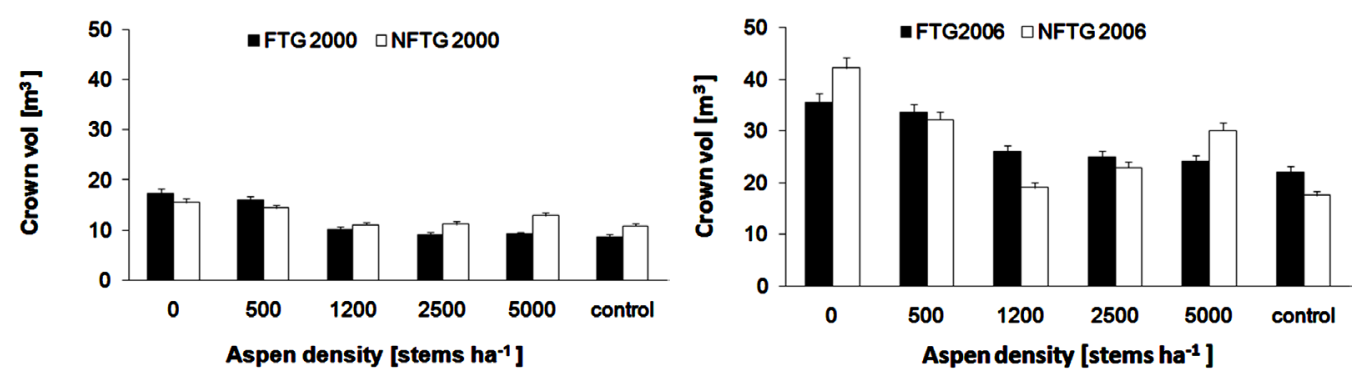

(c)

Figure 3. The effect of aspen density on FTG and NFTG lodgepole pine mean ( \pm SEM) DBH, height and crown volume in 2000 and 2006. (a) Based on diameter at breast height (DBH); (b) Based on height; (c) Based on crown volume.

Table 1. Regression of diameter and height at establishment and after two years growth against different aspen density treatments.

\begin{tabular}{|c|c|c|c|}
\hline Density & $R^{2}$ & $F$ & $P(f)$ \\
\hline \multicolumn{4}{|c|}{ Established diameter } \\
\hline All & 0.026 & 4.697 & 0.032 \\
\hline 5000 & 0.014 & 2.768 & 0.099 \\
\hline 2500 & 0.024 & 3.431 & 0.067 \\
\hline \multicolumn{4}{|c|}{ Diameter growth } \\
\hline All & 0.007 & 1.979 & 0.162 \\
\hline 5000 & 0.054 & 8.338 & 0.005 \\
\hline 2500 & 0.009 & 1.932 & 0.168 \\
\hline \multicolumn{4}{|c|}{ Established height } \\
\hline All & 0.013 & 2.660 & 0.105 \\
\hline 5000 & 0.002 & 1.286 & 0.259 \\
\hline 2500 & 0.009 & 1.856 & 0.176 \\
\hline \multicolumn{4}{|c|}{ Height growth } \\
\hline All & 0.000 & 0.595 & 0.442 \\
\hline 5000 & 0.000 & 0.499 & 0.481 \\
\hline 2500 & 0.000 & 0.402 & 0.528 \\
\hline
\end{tabular}

[The density when the regression changes from significant to non significant is shown]. 
Considering the leaf area index (LAI) ANOVA indicated a significant $(\mathrm{p}=0.003)$ difference among density treatments whereas an insignificant $(\mathrm{p}=0.614$ ) difference between FTG and NFTG pine (Figure 4). For light transmittance, the DIFN value was not significantly different among treatments $(\mathrm{p}=0.082)$ nor for FTG and NFTG pine $(\mathrm{p}=0.510)$. Generally LAI increased with increasing aspen density for both FTG and NFTG pine while an opposite trend was observed for DIFN. Mean annual DBH growth was not significantly $(p=0.12)$ different between FTG and NFTG pine and a similar mean annual DBH growth up to a DIFN value of 0.4 was observed for FTG pine and thereafter increased slightly. On the other hand, in NFTG pine mean annual DBH growth increased with increasing DIFN (Figure 5). However at DIFN $>0.3$ both treatments (FTG and NFTG pine) showed almost similar mean annual DBH growth.

\section{Discussion}

\subsection{Permanent Sample Plots}

In this study, 2500 stems $\cdot \mathrm{ha}^{-1}$ (sph) of aspen appears to be the critical density at which point pine diameter growth was not significantly affected whereas beyond this limit a significant effect may occur. Similar results have been reported by Newsome et al. $(2006,2010)$ where they did not find any significant pine responses until 2500 aspen sph. However lodgepole pine growth responses to reduction in neighboring aspen density have been variable in other south-central to southern BC studies. According to Heineman et al. (2008), the average aspen density threshold was $1867 \mathrm{sph}$ and pine stem diameter declined above this density level while Newsome et al. (2008) reported that 1000 sph of tall aspen was the threshold density on a sub-boreal spruce dry-warm and (SBSdw1) and interior Douglas-fir dry-cool (IDFdk3) biogeoclimatic zone in south-central British Columbia. In another study Newsome et al. (2004) reported that neither diameter nor any other metric of lodgepole pine growth improved within four years after different density reductions on an IDFxm (very dry mild) site. The lack of lodgepole pine growth response in the IDFxm study site may be due to the pine either not experiencing significant competition from aspen or being unable to respond to the aspen removal treatments because of other limiting factors such as soil moisture or nutrient availability, and possibly the origin and condition of pine at time of treatment (Newsome et al., 2004). That lodgepole pine in our study responded to aspen density treatment suggests that aspen were important competitors as different treatments were successful in relieving the competitive stress. However, it is uncertain at this time whether the difference will remain or if the results are in part a
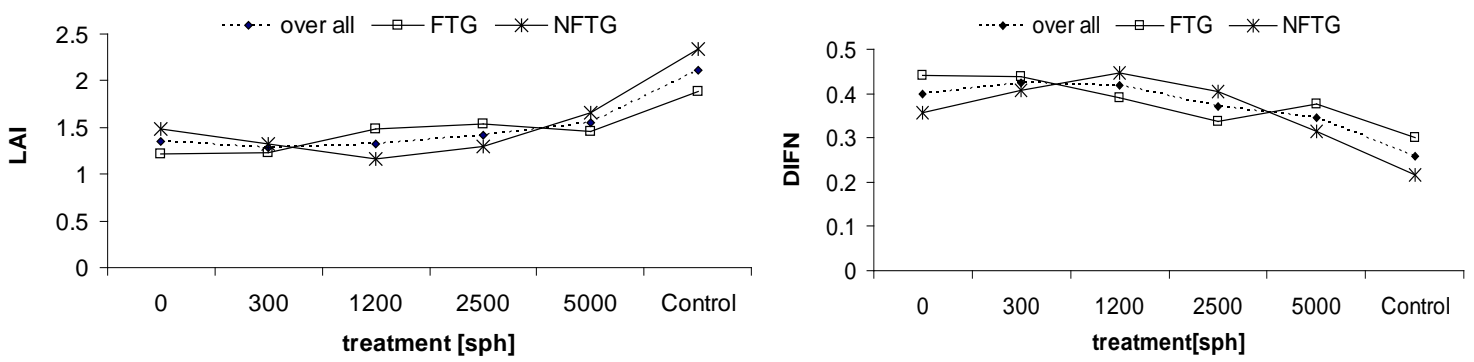

Figure 4. Mean leaf area index (LAI) and diffuse non-interceptance (DIFN) for FTG, NFTG and lodgepole pine by dif-ferent aspen density treatments in 2005 (least square means).

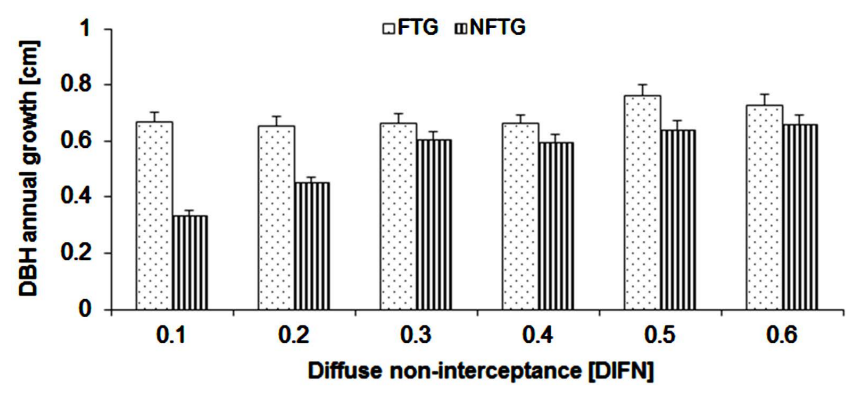

Figure 5. Mean annual DBH growth $( \pm$ SEM) as a function of DIFN for FTG and NFTG pine. 
function of the large tree size at the time of measurement and density treatments (stand was about 18 years old and it was 12 years old when the experiment was initiated). Moreover, it is important to note the experiments were designed to measure the effects of competition rather to investigate competitive mechanisms. Therefore this study can only speculate about reasons underlying the differing responses.

Pine height growth showed minimal response to aspen density classes. According to Lanner (1985), juvenile conifer height growth is absent at variable broadleaf density treatments and a similar result for lodgpole pine in relation to different aspen densities was reported by Newsome et al. (2008). Height responses tend not to be expressed until conifers are experiencing extreme stress and low vigor (Wagner, 2000; Newsome et al., 2008). On the other hand, a significant decrease of lodgepole pine HDR from 109 in the control to other treatments (ranges from 82 to 89) suggests that pine in the control were experiencing some stress over the growth period of 2000 to 2006 (Newton \& Comeau, 1990). The BC Ministry of Forest Spacing Guidebook suggests HDR > 90 are problematic (http://www.for.gov.bc.ca/tasb/legsregs/fpc/fpcguide/space/space-3.htm accessed 12 Aug 2014)。

\subsection{Response of Target FTG and NFTG Pine}

After six years, the insignificant differences in height, diameter or crown volume between FTG and NFTG pine and similar annual mean diameter growth of FTG and NFTG pine in response to different aspen densities (treatments) indicated that current free growing standard (1 m radius) may not large enough to observe the possible neighborhood competition effect. Perhaps the radius of influence from the aspen is larger than this, particularly in units where the target pine is roughly half the height of the competing aspen. Similar results have also been found for FTG criteria studies in Alberta (Lieffers et al., 2002; Lieffers et al., 2007). According to these studies a $1 \mathrm{~m}$ radius FTG criteria failed to make any inference about aspen spruce competition based on leaf area index and light transmission (Lieffers et al., 2002) or diameter and height increment growth (Lieffers et al., 2007). While in BC, the response of the competitive neighborhood between lodgpole pine and aspen showed a variable response in other south-central to southern interior studies. Based on 15 - 19 year old stands in the SBS and IDF Zones, Newsome et al. (2003) reported that competition between aspen and target pine was taking place in a $1.78 \mathrm{~m}$ neighborhood radius whereas in another study in the IDFxm, Newsome et al. (2010) found a neighborhood radius of 1.0-m in a 10-year-old stand. Newsome et al. (2006) also reported that aspen within a 2.56-m radius of target lodgepole pine were the main competitors in an 11-year-old stand in the sub-boreal pine-spruce very dry cool (SBPSxc) subzone of central BC.

Studies concerning other broadleaf-conifer mixtures showed even larger competitive neighborhoods. Lieffers et al. (2002) reported that plots with less than $2 \mathrm{~m}$ radius poorly represented light competition between aspen and white spruce in $10-12 \mathrm{~m}$ tall boreal stands, and suggested that plots with 10-m radius would be required to assess understory light conditions. In 11-year-old Douglas-fir and paper birch stands in the southern BC interior, Simard and Sachs (2004) determined that the size of the competitive neighborhood was 3 - $4 \mathrm{~m}$. In an unpublished study of 20 year old spruce and paper birch in the SBS near Prince George, we found there was no change in DBH growth until the brush free radius was $4 \mathrm{~m}$. The size of competitive neighborhoods may vary due to differences in the height between broadleaf and conifer species (Newsome et al., 2006) or it may be site specific and related to the vigor of the crop (conifer) tree. In our investigation, the stand was 18 years old during the last field inventory and it might have a competitive neighborhood larger than $1 \mathrm{~m}$. Keddy (1990) reported that tall individuals capture more light than shorter individuals and they also cast shade over a greater distance potentially reducing the vigor of the shorter individuals.

This study revealed that the leaf area index (LAI) increased with increased aspen density. This is consistent with other studies in the boreal forest (Comeau et al., 2004). Based on Comeau et al. (2004) work, a significantly lower LAI was reported when young aspen stands in the boreal forest were thinned to densities of 1000 and 2000 compared to the LAI at densities $\geq 3000 \mathrm{sph}$. Gower et al. (1996) and Lieffers et al. (2002) reported that the stand LAI peaked between 15 - 25 years and thereafter starts to decrease. For FTG and NFTG pine, an insignificant variation for LAI suggests that the current free growing criteria may require further investigation to verify its applicability in mixedwood management. Our light transmittance data are not able to predict any variability among different density treatments and free growing criteria (FTG and NFTG). However our data suggests that in high aspen density stands understory pine could go through a competitive bottleneck of low light conditions at early age as stand leaf area usually peaks at this age (Lieffers et al., 2002). The current FTG definition based on $1 \mathrm{~m}$ radius plots was unable to differentiate the competitive impacts of aspen for light on pine DBH growth. 


\section{Conclusions}

It is desirable to maintain a density of broadleaf species for maximizing conifer species growth in mixedwood stands as broadleaf species like trembling aspen provide positive contributions to stand structure, biological diversity, nutrient cycling and productivity (Morrison et al., 1991; Taylor \& Cozens, 1994; Simard et al., 2005; Park et al., 2014). The non significant difference in pine performance up to 2500 sph suggests lodgepole pine in the SBSwk1 of central BC performs well in neighbourhoods with $\leq 2500$ aspen sph. However, longer assessments periods are required before making any firm conclusions about aspen and lodgpole pine competition. Moreover this study also suggests the need for ecosystem-specific guidelines for managing young aspen and lodgepole pine mixtures to maximize pine growth.

The appropriateness of the free growing radius of $1 \mathrm{~m}$, the competitive neighborhood, brings into question the current free growing guidelines. Differences in pine performance as a result of FTG and NFTG treatments are not well-justified, and we cannot yet say whether the current "free growing" guidelines are biologically appropriate for pine-aspen stands in the SBSwk1 zone. However the FTG and NFTG treatments applied in this study will help to advance our understanding whether or not the current standards are appropriate for producing the expected crop/conifer tree growth.

\section{Acknowledgements}

This ongoing project was established by the Ministry of Forests and Range, Prince George, BC (Gord Dow and Tony Letchford) and Carrier Lumber Ltd. Funding has been provided by Forest Renewal BC (2000-2002), Forest Innovation Investment (2002-2004), Forest Investment Account (2005-2006), Forest Science Program (2008) and the UNBC Mixedwood Ecology and Management Program. Peter Fielder and Phil Comeau provided indispensable help and guidance with the LAI data.

\section{References}

British Columbia Ministry of Forests (2000). Establishment to Free Growing Guidebook-Kamloops Forest Region (Version 2.2). BC Ministry of Forests, Forest Practices Branch, Victoria, B.C., Canada.

British Columbia Ministry of Forests (2005). Guide to the Evaluation of FSP Stocking and Related Standards. BC Ministry of Forests, Forest Practices Branch, Victoria, B.C., Canada.

Burton, P. J. (1993). Some Limitations Inherent to Static Indices of Plant Competition. Canadian Journal of Forest Research, 23, 2141-2152. http://dx.doi.org/10.1139/x93-267

Chen, H. Y. H., Klinka, K., \& Kayahara, G. J. (1996). Effects of Light on Growth, Crown Architecture, and Specific Leaf Area for Naturally Established Pinus contorta var. latifolia and Pseudotsuga menziesii var. glauca saplings. Canadian Journal of Forest Research, 26, 1149-1157. http://dx.doi.org/10.1139/x26-128

Chen, H. Y. H., Krestov, P. V., \& Klinka, K. (2002). Trembling Aspen Site Index in Relation to Environmental Measures of Site Quality at Two Spatial Scales. Canadian Journal of Forest Research, 32, 112-119. http://dx.doi.org/10.1139/x01-179

Comeau, P. G., Filipescu, N. C., Kabzems, R., \& DeLong, C. (2004). Early Growth of White Spruce Underplanted Beneath Spaced and Unspaced Aspen Stands in North-Eastern British Columbia. Canadian Journal of Forest Research, 34, 22772283. http://dx.doi.org/10.1139/x04-105

Comeau, P. G., Gendron, F., \& Letchford, T. (1998). A Comparison of Several Methods of Estimating Light under a Paper Birch Mixedwood Stand. Canadian Journal of Forest Research, 28, 1843-1850. http://dx.doi.org/10.1139/x98-159

Comeau, P. G., Heineman, J. L., \& Newsome, T. (2006). Evaluation of Relationships between Understory Light and Aspen Basal Area in the British Columbia Central Interior. Forest Ecology and Management, 226, 80-87. http://dx.doi.org/10.1016/j.foreco.2005.12.060

Comeau, P.G. (2001). Relationships between Stand Parameters and understory Light in Boreal Aspen Stands. Journal of Ecosystems and Management, 1, 103-110.

Coopersmith, D., Sagar, B., \& Thompson, D. (2000). Ten-Year Results of the Bear Mountain Mixedwood Trial (EP1077): The Effect of Overtopping Aspen Canopies on White Spruce Seedling Growth and Seedling Microclimate. BC Min. For., Prince George Forest Region, Forest Research Note PG-23, 12 pp.

DeLong, C., \& Tanner, D. (1996). Effect of Aspen Competition on Survival and Growth of Lodgepole Pine and White Spruce. In P. G. Comeau, G. J. Harper, M. E. Blache, J. O. Boateng, \& K. D. Thomas (Eds.), Ecology and Management of B.C. Hardwoods (pp. 203-204). Victoria, BC: Canada Forest Service and the BC Ministry of Forests.

Frivold, L. H. (1985). Mixed Broadleaved-Coniferous Stands: Some Silvicultural Considerations. In B. Hahhlund, \& G. Peterson (Eds.), Broadleaves in Boreal Silviculture: An Obstacle or an Asset (pp. 207-221). Umeå: Department of Silviculure, Swedish University of Agricultural Science. 
Gerlach, J. P., Reich, P. B., Puettmann, K., \& Baker, T. (1997). Species, Diversity, and Density Affect Tree Seedling Mortality from Armillaria Root Rot. Canadian Journal of Forest Research, 27, 1509-1512. http://dx.doi.org/10.1139/x97-098

Gower, S. T., McMurtrie, R. E., \& Murty, D. (1996). Aboveground Net Primary Production Decline with Stand Age: Potential Causes. Tree, 11, 378-382. http://dx.doi.org/10.1016/0169-5347(96)10042-2

Hawkins, C. D. B., \& Dhar, A. (2013). Birch (Betula papyrifera) White Spruce (Picea glauca) Interactions in Mixedwood Stands: Implications for Management. Journal of Forest Science, 59, 137-149.

Hawkins, C. D. B., Dhar, A., \& Lange, J. (2013). Vegetation Management with Glyphosate Has Little Impact on Understory Species Diversity or Tree Growth in a Sub Boreal Spruce Plantation: A Case Study. Plant Biosystems, 147, $105-114$. http://dx.doi.org/10.1080/11263504.2012.736421

Hawkins, C. D. B., Dhar, A., \& Rogers, B. J. (2012). How Much Birch (Betula papyrifera) Is Too Much for Maximizing Spruce (Picea glauca) Growth: A Case Study in Boreal Spruce Plantation Forests. Journal of Forest Science, 58, $314-327$.

Heineman, J. L., Simard, S. W., Sachs, D. L., \& Mather, W. J. (2008). Trembling Aspen Removal Effects on Lodgepole Pine in Southern Interior British Columbia: Ten Year Results. Western Journal of Applied Forestry, 24, 17-23.

Hibbs, D. E., Emmingham, W. H., \& Bondi, M. C. (1989) Thinning Red Alder: Effects of Method and Spacing. Forest Science, 35, 16-29.

Kabzems, R., \& Garcia, O. (2004). Structure and Dynamics of Trembling Aspen-White Spruce Mixed Stands near Fort Nelson, BC. Canadian Journal of Forest Research, 34, 384-395. http://dx.doi.org/10.1139/x03-254

Klinka, K., \& Scagel, A. M. (1984). Selected Ecological Characteristics of Some Tree and Shrub Species in British Columbia: Genera Juniperus, Taxus, Populus, Alnus, Betula, Quercus, Prunus, Rhamnus, Acer, Cornus, and Arbutus. Coquitlam: Canadian Cartographics Ltd.

Lanner, R. L. (1985). On the Sensitivity of Height Growth to Spacing. Forest Ecology and Management, 3, 143-148. http://dx.doi.org/10.1016/0378-1127(85)90030-1

Lees, J. C. (1966). Release of White Spruce from Aspen Competition in Alberta's Spruce-Aspen Forest. Publication 1163, Ottawa: Canada Department of Forest. http://cfs.nrcan.gc.ca/pubwarehouse/pdfs/31444.pdf

Lieffers, J. V., Pinno, D. B., \& Stadt, J. K. (2002). Light Dynamics and Free-to-Grow Standards in Aspen Dominated Mixedwood Forests. The Forestry Chronicle, 78, 37-45. http://dx.doi.org/10.5558/tfc78137-1

Lieffers, V. J., Stadt, K. J., \& Feng, Z. (2007). Free-to-Grow Regeneration Standards Are Poorly Linked to Growth of Spruce in Boreal Mixedwoods. The Forestry Chronicle, 83, 818-824. http://dx.doi.org/10.5558/tfc83818-6

Man, R., \& Lieffers, V. J. (1999). Are Mixtures of Aspen and White Spruce More Productive than Single Species Stands? The Forestry Chronicle, 75, 505-513. http://dx.doi.org/10.5558/tfc75505-3

Meidinger, D., Pojar, J., \& Harper, W. L. (1991). Sub-Boreal Spruce Zone. In D. Meidinger, \& J. Pojar (Eds.), Ecosystems of British Columbia (pp. 195-207). Victoria: BC Ministry of Forests.

Morrison, D. J., Merler, H., \& Norris, D. (1991). Detection, Recognition and Management of Armillaria and Phellinus Root Diseases in the Southern Interior of British Columbia. Canada-British Columbia Partnership Agreement on Forest Resource Development: FRDA II, FRDA Report 179. Victoria: British Columbia Ministry of Forests.

Newsome, T., Heineman, J. L., \& Nemec, A. (2003). Competitive Effects of Trembling Aspen on Lodgepole Pine Performance in the SBS and IDF Zones of the Cariboo-Chilcotin Region of South-Central British Columbia. Research Branch, BC. Ministry of Forest, Victoria Technical Report 005. www.for.gov.bc.ca/hfd/pubs/Docs/Tr/Tr005.htm

Newsome, T., Heineman, J. L., \& Nemec, A. (2004). Early Effects of Manipulating Aspen Density on Lodgepole Pine Performance, Aspen Sucker Production, and Stand Development in the IDFxm Subzone near Williams Lake, B.C. Technical Report 015, Victoria: Research Branch, B.C. Ministry of Forests.

Newsome, T., Heineman, J. L., \& Nemec, A. (2006). Effects of Variable Aspen Retention on Stand Development, Aspen Sucker Production and Growth of Lodgepole Pine in the SBSdw1 Variant of South-Central British Columbia. Technical Report 032, Victoria: Research Branch, B.C. Ministry of Forests, 31 p.

Newsome, T., Heineman, J. L., \& Nemec, A. (2008). Competitive Interactions between Juvenile Trembling Aspen and Lodgepole Pine: A Comparison of Two Interior British Columbia Ecosystems. Forest Ecology and Management, 255, 29502962. http://dx.doi.org/10.1016/j.foreco.2008.02.001

Newsome, T., Heineman, J. L., \& Nemec, A. (2010). A Comparison of Lodgepole Pine Responses to Varying Levels of Trembling Aspen Removal in Two Dry South-Central British Columbia Ecosystems. Forest Ecology and Management, 259, 1170-1180. http://dx.doi.org/10.1016/j.foreco.2010.01.003

Newton, M., \& Comeau, P. G. (1990). Control of Competing Vegetation. In D. P. Lavender, R. Parish, C. M. Johnson, G. Montgomery, A. Vyse, R. A. Willis, \& D. Winston (Eds.), Regenerating British Columbia's Forests (pp. 256-265). Vancouver: University of British Columbia Press. 
Park, A., Puettmann, K., Edward Wilson, E., Messier, M., Kames, S., \& Dhar, A. (2014). Can Boreal and Temperate Forest Management Be Adapted to the Uncertainties of 21st Century Climate Change? Critical Reviews in Plant Sciences, 33, 251-285. http://dx.doi.org/10.1080/07352689.2014.858956

Peng, C., Liu, J., Dang, Q., Zhou, X., \& Apps, M. (2002). Developing Carbon-Based Ecological Indicators to Monitor Sustainability of Ontario's Forests. Ecological Indicators, 1, 235-246. http://dx.doi.org/10.1016/S1470-160X(02)00010-9

Prévost, M., \& Pothier, D. (2003). Partial Cuts in a Trembling Aspen-Conifer Stand: Effects on Micro-Environmental Conditions and Regeneration Dynamics. Canadian Journal of Forest Research, 33, 1-15. http://dx.doi.org/10.1139/x02-147

Simard, S. W., \& Sachs, D. L. (2004). Assessment of Interspecific Competition Using Relative Height and Distance Indices in an Age Sequence of Seral Interior Cedar-Hemlock Forests in British Columbia. Canadian Journal of Forest Research, 34, 1228-1240. http://dx.doi.org/10.1139/x04-008

Simard, S. W., Hagerman, S. W., Sachs, D. L., Heineman, J. L., \& Mather, W. J. (2005). Conifer Growth, Root Disease, and Plant Community Responses to Mechanical and Chemical Control of Birch and Aspen in Southern British Columbia's Temperate Mixed Forests. Canadian Journal of Forest Research, 35, 843-859. http://dx.doi.org/10.1139/x05-010

Simard, S. W., Heineman, J. L., Mather, W. J., Sachs, D. L., \& Vyse, A. (2001). Effects of Operational Brushing on Conifers and Plant Communities in the Southern Interior of British Columbia: Results from PROBE 1991-2000. B.C. Handbook No. 48, Victoria: B.C. Ministry of Forests Land Management, 398 p.

Taylor, S. P., \& Cozens, R. D. (1994). Limiting White Pine Weevil Attacks by Side and Overstory Shade in the Prince George Forest Region. Journal of Entomology Society BC, 91, 37-42.

Wagner, R. G. (2000). Competition and Critical-Period Thresholds for Vegetation Management Decisions in Young Conifer Stands. The Forestry Chronicle, 76, 961-968. http://dx.doi.org/10.5558/tfc76961-6

Yang, R. C. (1989). Growth Response of White Spruce to Release from Trembling Aspen. Inf. Rep. NOR-X-302, Edmonton: For. Can. 
Scientific Research Publishing (SCIRP) is one of the largest Open Access journal publishers. It is currently publishing more than 200 open access, online, peer-reviewed journals covering a wide range of academic disciplines. SCIRP serves the worldwide academic communities and contributes to the progress and application of science with its publication.

Other selected journals from SCIRP are listed as below. Submit your manuscript to us via either submit@scirp.org or Online Submission Portal.
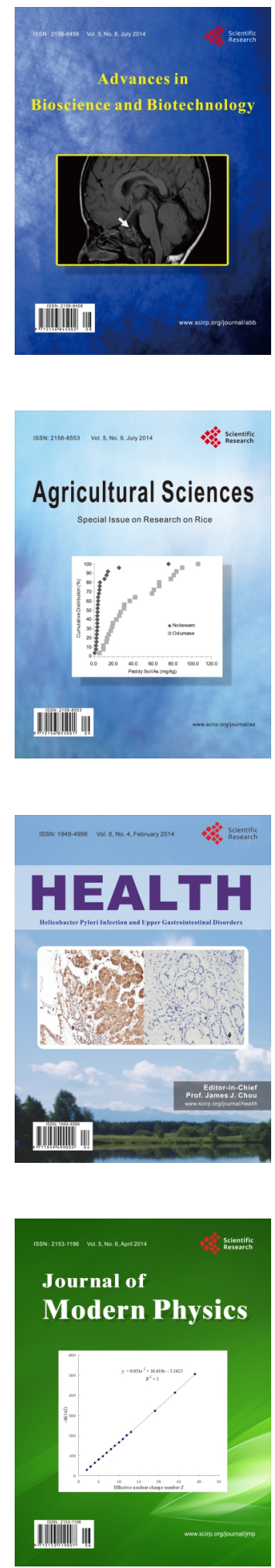
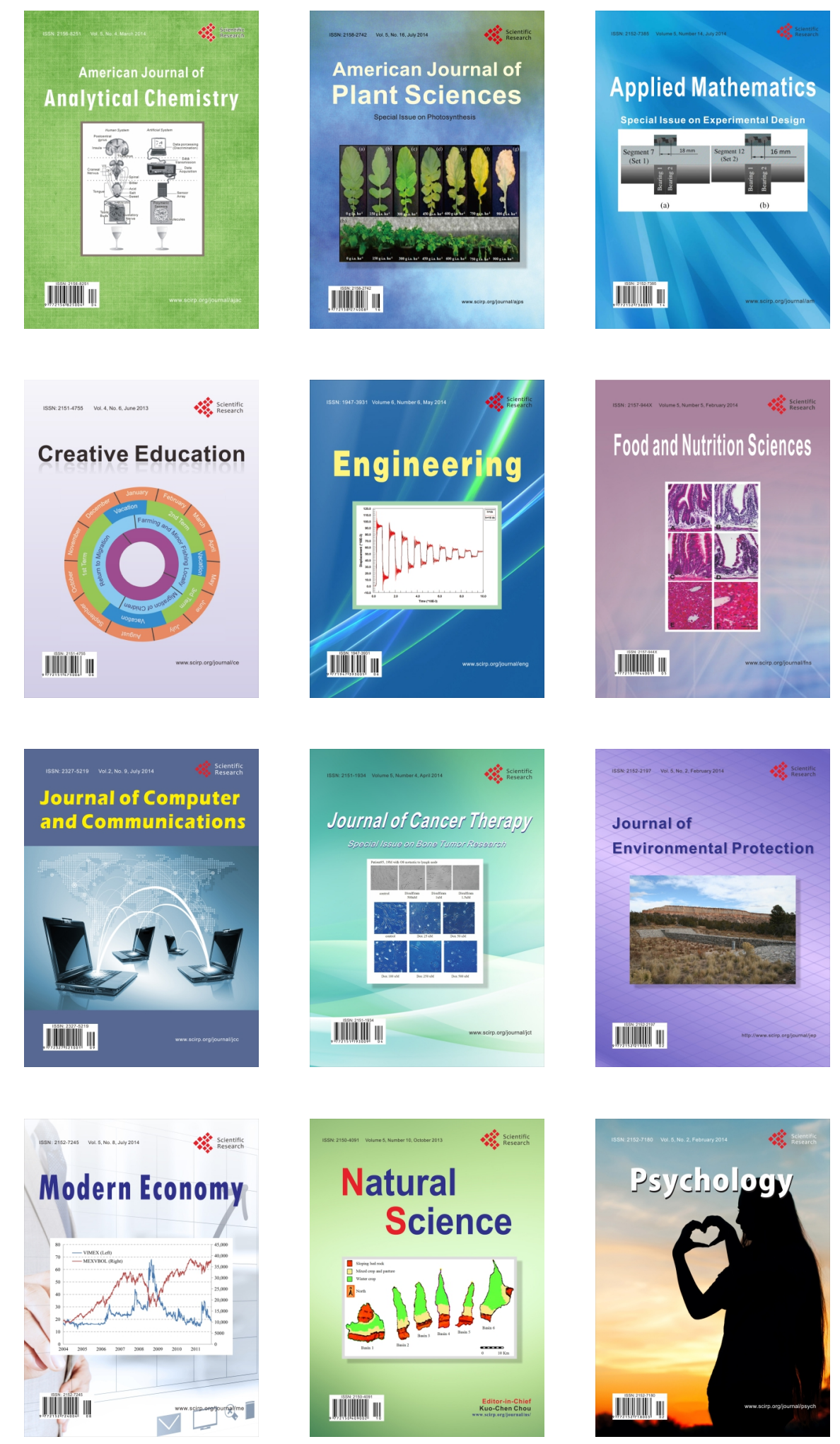